\title{
Vitamin D Efficiency in Pregnancy: An Updated Viewpoint in Indian Scenario*
}

\author{
Manish Maladkar", Srividya Sankar, Kushal Kamat \\ Aristo Pharmaceuticals Pvt. Ltd., Mumbai, India \\ Email: "scientific@aristopharma.org
}

Received 6 March 2015; accepted 21 March 2015; published 26 March 2015

Copyright (C) 2015 by authors and Scientific Research Publishing Inc.

This work is licensed under the Creative Commons Attribution International License (CC BY). http://creativecommons.org/licenses/by/4.0/

cC) (7) Open Access

\begin{abstract}
A decade ago identified as bone-building mineral improving calcium absorption, today new research opens potentials of Vitamin $D$ in spectrum of diseases from diabetes, hypertension to cancer including special population like pregnancy \& lactation. As calcium demands increase during pregnancy, Vitamin D status becomes crucial for optimal maternal \& fetal outcomes. Adverse health outcomes such as preeclampsia, low birth weight, neonatal hypocalcemia, bone fragility \& increased incidence of autoimmune diseases have been linked to low Vitamin D levels during pregnancy \& infancy. Vitamin D deficiency is common during pregnancy \& lactation despite widespread use of prenatal vitamins, because these are inadequate to maintain normal Vitamin $D$ levels. The current IOM (US) as well as ICMR (India) recommendations for Vitamin D supplementation is not sufficient to maintain the optimal levels of serum $25(\mathrm{OH}) \mathrm{D}$ above $30 \mathrm{ng} / \mathrm{ml}$ required during pregnancy. It may therefore be judicious to include screening of all pregnant women for Vitamin D levels as a part of routine antenatal care and supplementation should be considered if deficiency persists. Till date interventional trials in special population suggest that administration of Vitamin D during pregnancy \& lactation is safe \& beneficial for optimal maternal \& fetal outcomes. When Vitamin $D$ deficiency is identified during pregnancy, most experts agree that up to 2000 IU/day of Vitamin D is safe. This review elaborates Vitamin D deficiency in Indian scenario and the need for Vitamin $D$ supplementation, expounds and exercises the facts for implementation of Vitamin D supplementation to be advised when planning for pregnancy, current recommendations and implications of Vitamin D deficiency during pregnancy and lactation.
\end{abstract}

\section{Keywords}

Vitamin D, Vitamin D Deficiency, Indian, Pregnancy, Lactation

\footnotetext{
"The paper is a representation for call on consensus for benefits of Vitamin D supplementation, adequate dose and level of Vitamin D in pregnancy and lactation particularly in Indian scenario.

\#Corresponding author.
} 


\section{Introduction}

As the statistics keep surfacing at the alarming pace, Vitamin D deficiency is recognized as the most un-treated nutritional deficiency currently in the world [1]-[3]. Vitamin D deficiency is a significant public health problem in both developed and developing countries including India [4]. Although India is a tropical country with abundant sunshine; still Vitamin D deficiency is very common in India in all age groups and both sexes across the country [5]. The skeletal action of Vitamin D is to maintain calcium homeostasis and bone health. In addition, it is now known to be involved in extra-skeletal functions in diverse tissues and organs, including the pancreas, heart, brain and immunomodulation [6]-[8]. Several clinical studies suggest the possible association between low Vitamin D levels and potential adverse outcomes of pregnancy [9]-[12]. The widespread Vitamin D deficiency in pregnant women and lactating mother's calls for a view to define optimum level of Vitamin D and the adequate amount of Vitamin D intake required to maintain optimum levels in these populations. The aim of the paper is to provide a comprehensive picture of Vitamin D status among pregnant women and lactating mothers countrywide. It illustrates the summation of Indian studies projecting deficiency statistics across the country firmly establishing the grave need to tackle the issue. It particularizes on the need to raise the desired Vitamin D level in pregnancy and lactation $>30 \mathrm{ng} / \mathrm{mL}$ from the conventional $>20 \mathrm{ng} / \mathrm{mL}$ as suggested by the Institute of Medicine (IOM), US. It also discusses the safe dose that can be advocated among pregnant women and lactating mothers. The review gives details of the benefits of Vitamin D supplementation in pregnancy and lactation and insights the current recommendations by different international organization for Vitamin D supplementation in pregnancy and lactation. It discusses utility of Vitamin D as preconceptional nutrition as well as the possible benefits of Vitamin D supplementation in first trimester, a section less explored. In order to ease data representation, all 25(OH) D levels in this review are interpreted in a single concentration unit—nanogram per milliliter $(\mathrm{ng} / \mathrm{mL})$ and all Vitamin D doses as interpreted in International Unit (IU). Representation in single unit is aimed to allow easy comparison among studies. This could enable physicians to optimally diagnose and treat the broader concern of Vitamin D deficiency among Indian population.

\section{Need for Vitamin D Feed}

Vitamin D deficiency is common in pregnant women (5\% - 50\%) and in breastfed infants (10\% - 56\%), despite the widespread use of prenatal vitamins, because these are inadequate to maintain normal Vitamin D levels ( $\geq 32$ $\mathrm{ng} / \mathrm{mL}$ ) [9]. Although being a tropical country, Vitamin D deficiency is documented high in pregnant women \& lactating mothers in India. Table 1 and Table 2 summarize studies depicting the status of Vitamin D in pregnancy and lactation among Indian population. Insufficient outdoor activity in urban areas, dark skin colour, poor dietary calcium causing secondary Vitamin D deficiency and environmental pollution could be few risk factors that account for high prevalence of Vitamin D deficiency in the country [13]-[16].

\subsection{The Significance of Vitamin D in Pregnancy}

During initial to mid-trimesters, the fetal organs begin to develop and there is start of skeleton formation in form of collagen matrix. The skeleton of the fetus begins to calcify in the last trimester, thereby increasing maternal demand for calcium. This demand is met by increased production of $1,25(\mathrm{OH})_{2} \mathrm{D}$ by the mother's kidneys \& placenta. Circulating concentrations of $1,25(\mathrm{OH})_{2}$ D gradually increase during the 1 st $\&$ 2nd trimesters, owing to an increase in Vitamin D-binding protein concentrations in the maternal circulation. However, the free levels of $1,25(\mathrm{OH})_{2} \mathrm{D}$, which are responsible for enhancing intestinal calcium absorption, are only increased during the 3rd trimester [32]. Fetal calcium levels are higher than maternal throughout gestation. There is active transport of calcium across the placenta [33]. Fetal Vitamin D concentrations are up to $20 \%$ lower than maternal as measured in cord blood. Vitamin D deficiency during pregnancy is linked with preeclampsia [34], gestational diabetes mellitus, preterm labour [35] [36] and an increased risk for caesarean section delivery [37]. The importance of Vitamin D for fetal \& infant skeletal development has long been recognized. In full-term infants, impaired fetal bone ossification correlated with maternal Vitamin D deficiency [38]. Maternal Vitamin D deficiency is associated with subtle fetal bone abnormalities like shorter knee-heel length [39], low birth weight [40] \& high risk of being small for gestational age (SGA) [41].

\subsection{The Significance of Vitamin D in Lactation}

During lactation, it is required that the mother increase the efficiency of dietary absorption of calcium to ensure 
Table 1. Studies depicting Vitamin D status in pregnant women-Indian studies.

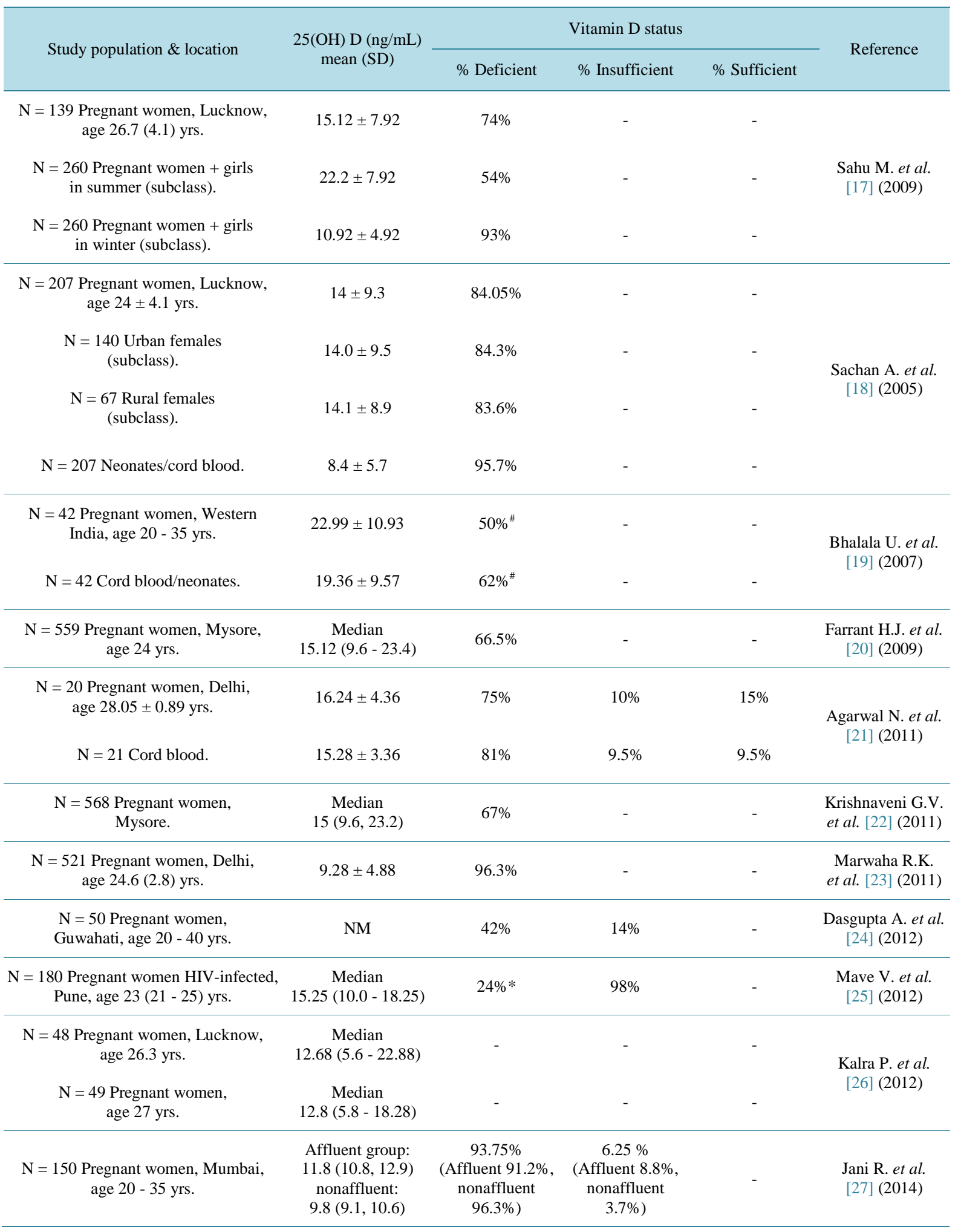

Notes: All 25(OH) D values have been shown in nanogram/milliliter (ng/mL). To convert from nanomoles per liter to nanogram per milliliter, nanomoles per liter values were divided by 2.5. Vitamin D deficiency is defined as $25(\mathrm{OH}) \mathrm{D}<20 \mathrm{ng} / \mathrm{mL}$, insufficiency as $20-29 \mathrm{ng} / \mathrm{mL}$ and sufficiency as $\geq 30 \mathrm{ng} / \mathrm{mL}$. *Vitamin D deficiency defined as $<10 \mathrm{ng} / \mathrm{ml}$ in these studies. \#Vitamin D deficiency defined as $<25 \mathrm{ng} / \mathrm{ml}$ in these studies. Abbreviations: N, Number of subjects; NM, not measured; 25(OH) D, 25 Hydroxy Vitamin D; ng/mL, nanogram per milliliter. 
Table 2. Studies depicting Vitamin D status in lactating women-Indian studies.

\begin{tabular}{|c|c|c|c|c|c|}
\hline \multirow{2}{*}{ Study population \& location } & \multirow{2}{*}{$\begin{array}{c}25(\mathrm{OH}) \mathrm{D}(\mathrm{ng} / \mathrm{mL}) \\
\text { mean }(\mathrm{SD})\end{array}$} & \multicolumn{3}{|c|}{ Vitamin D status } & \multirow{2}{*}{ Reference } \\
\hline & & \% Deficient & \% Insufficient & \% Sufficient & \\
\hline N = 35 Infants, 3 months old. & $18.19 \pm 9.74$ & $80 \%{ }^{\#}$ & - & - & $\begin{array}{l}\text { Bhalala U. et al. } \\
\text { [19] (2007) }\end{array}$ \\
\hline $\mathrm{N}=180$ Healthy lactating mothers. & $10.88 \pm 5.8$ & $47.8 \% *$ & - & - & \multirow[b]{2}{*}{$\begin{array}{l}\text { Seth A. et al. } \\
\text { [28] (2009) }\end{array}$} \\
\hline $\begin{array}{l}\mathrm{N}=180 \text { Exclusively breast fed } \\
\text { infants, } 2 \text { - } 24 \text { week old. }\end{array}$ & $11.6 \pm 8.3$ & $43.2 \% *$ & - & - & \\
\hline $\begin{array}{c}\mathrm{N}=60 \text { Lactating mothers, } \\
\text { age } 25.0(2.0) \text { yrs. }\end{array}$ & $9.06 \pm 4.78$ & $98.3 \%$ & - & - & \multirow{2}{*}{$\begin{array}{l}\text { Mehrota P. et al. } \\
\text { [29] (2010) }\end{array}$} \\
\hline $\begin{array}{l}\mathrm{N}=60 \text { Breastfed infants, } \\
\text { age } 3.0(0.14) \text { months. }\end{array}$ & $9.03 \pm 4.63$ & $100 \%$ & - & - & \\
\hline N = 97 Lactating mothers. & $9.85 \pm 6.28$ & - & - & - & \multirow{2}{*}{$\begin{array}{l}\text { Agarwal N. } \\
\text { et al. [30] (2010) }\end{array}$} \\
\hline $\mathrm{N}=97$ Exclusively breastfed infants. & $12.59 \pm 8.37$ & - & - & - & \\
\hline $\begin{array}{l}\mathrm{N}=98 \text { Lactating mothers, Delhi, } \\
\text { age } 23.3 \text { (3.3) yrs. }\end{array}$ & $\begin{array}{c}\text { Median } \\
9.8(5.0-13.8)\end{array}$ & $92.6 \%$ & - & - & \multirow{2}{*}{$\begin{array}{l}\text { Jain V. et al. } \\
\text { [31] (2011) }\end{array}$} \\
\hline $\begin{array}{c}\mathrm{N}=98 \text { Breastfed Infants, } 58.2 \% \text { male, } \\
\text { age } 13.6(2.2) \text { weeks. }\end{array}$ & $\begin{array}{c}\text { Median } \\
10.1(2.5-17.1)\end{array}$ & $86.5 \%$ & - & - & \\
\hline $\begin{array}{l}N=342 \text { Lactating mothers, } \\
6 \text { - } 8 \text { weeks postpartum. }\end{array}$ & $7.84 \pm 3.32$ & $99.7 \%$ & - & - & \multirow[t]{2}{*}{$\begin{array}{l}\text { Marwaha R.K. } \\
\text { et al. [23] (2011) }\end{array}$} \\
\hline $\mathrm{N}=342$ Exclusively breastfed infants. & $8.92 \pm 4.2$ & $98.8 \%$ & - & - & \\
\hline
\end{tabular}

Notes: All 25(OH) D values have been shown in nanogram/milliliter $(\mathrm{ng} / \mathrm{mL})$. To convert from nanomoles per liter to nanogram per milliliter, nanomoles per liter values were divided by 2.5. Vitamin D deficiency is defined as $25(\mathrm{OH}) \mathrm{D}<20 \mathrm{ng} / \mathrm{mL}$, insufficiency as $20-29 \mathrm{ng} / \mathrm{mL}$ and sufficiency as $\geq 30 \mathrm{ng} / \mathrm{mL}$. *Vitamin D deficiency defined as $<10 \mathrm{ng} / \mathrm{ml}$ in these studies. \#Vitamin D deficiency defined as $<25 \mathrm{ng} / \mathrm{ml}$ in these studies. Abbreviations: N, Number of subjects; 25(OH) D, 25 Hydroxy Vitamin D; ng/mL, nanogram per milliliter.

adequate calcium content in her milk. Breast milk Vitamin D correlates well with maternal Vitamin D concentrations so breast-fed infants are at risk of persistent Vitamin D deficiency if the mother is deficient. In the first 6 8 weeks of postnatal life, the Vitamin D status of a neonate is dependent largely on Vitamin D that is acquired through placental transfer in utero, as evidenced by the direct linear relationship between maternal and cord blood levels of 25(OH) D [42]. In most infants, Vitamin D stores acquired from the mother are depleted by approximately 8 weeks of age [43]. Human milk contains a very low concentration of Vitamin D (approximately 20 - $60 \mathrm{IU} / \mathrm{L}$ ), which represents $1.5 \%$ - 3\% of the maternal level [44]. This low concentration is not sufficient to maintain an optimal Vitamin D level in the newborns if exposure to sunlight is limited. The maternal Vitamin D status determines the breast milk Vitamin D concentration. The first step toward achieving Vitamin D sufficient breast milk must address the Vitamin D supplementation required to achieve Vitamin D sufficiency in the mother. Low Vitamin D predisposes to hypocalcaemia in the immediate postpartum period \& then rickets over the next few months [39]. Symptomatic Vitamin D deficiency manifests as craniotabes, rickety rosary, swelling of the ends of long bones, frontal bossing of the skull, hypocalcaemic seizures or tetany and slow motor development. Hypocalcaemia in early infancy is commonly associated with functional or organic hypoparathyroidism [45]. Rickets during infancy has been associated with higher prevalence of lower respiratory tract infections, [46] which remain one of the largest causes of infant mortality in India.

\section{Defining Vitamin D levels in Pregnancy and Lactation}

Serum 25(OH) D levels is the best available biomarker for diagnosis of Vitamin D deficiency. Vitamin D researchers recommend that the serum $25(\mathrm{OH}) \mathrm{D}$ concentrations should be at least $30 \mathrm{ng} / \mathrm{mL}$ in order to provide optimal health outcomes. Serum 25(OH) D levels $<30 \mathrm{ng} / \mathrm{mL}$ may be considered insufficient/ deficient. Maintenance of adequate levels of serum $25(\mathrm{OH}) \mathrm{D}$ is essential to sustain skeletal \& extra-skeletal benefits of Vita- 
min D. A number of guidelines \& studies suggest that in general population screening of Vitamin D levels is not required; treatment can be initiated without finding the Vitamin D levels. Vitamin D levels can be measured irrespective of fasting \& non-fasting state. Various clinical studies establish the need of Vitamin D supplementation in pregnancy and lactation. As Vitamin D supplementation sets to be a routine in pregnant women and lactating mothers, there is need to define the optimum level of Vitamin D in these population. The correlation between Vitamin D levels and intestinal calcium absorption, maximal PTH suppression, bone fracture prevention, and bone turnover have been established with respect to Vitamin D levels and indicate that levels $>32 \mathrm{ng} / \mathrm{mL}$ are required for sufficiency [47] [48]. These levels can also be applied in pregnancy and during lactation as the above stages correlate with maternal and fetal outcomes [49]. In mothers, Vitamin D sufficiency (32 - $100 \mathrm{ng} / \mathrm{ml})$ is related to adequate calcium balance, parathyroid hormone levels. Severe Vitamin D deficiency ( $<10 \mathrm{ng} / \mathrm{ml})$ is related to increased risk of preeclampsia, calcium malabsorption, bone loss, poor weight gain, myopathy, higher parathyroid hormone levels while Vitamin D deficiency/insufficiency (10 - $32 \mathrm{ng} / \mathrm{ml})$ is related to bone loss and subclinical myopathy. Similarly in infants, severe Vitamin D deficiency $(<10 \mathrm{ng} / \mathrm{ml})$ is related to small for gestational age, neonatal hypocalcemia, hypocalcemic seizures, infantile heart failure, enamel defects, large fontanelle, congenital rickets, rickets of infancy if breastfed while Vitamin D deficiency/insufficiency (10 - $32 \mathrm{ng} / \mathrm{ml})$ is related to Neonatal hypocalcemia, reduced bone mineral density, rickets of infancy if breastfed [9].

The benefits of maintaining Vitamin D levels in pregnancy is mounting with various studies documenting higher target of Vitamin D level for optimum outcomes. Two large trials, one covered by National Institute of Child Health and Human Development (NICHD), Hollis B.W et al. [50] and Thrasher Research, Wagner C.L et al. [51] suggest levels $>32 \mathrm{ng} / \mathrm{ml} \&$ above are safe in pregnancy. No single cases of adverse events were reported at these levels and higher Vitamin D levels were suggestive of reduction in the risk of pregnancy complications like maternal infections, preterm labor and preterm birth. In US study accessing the risk of Preeclampsia, a five-fold increased risk of pre-eclampsia was seen in pregnant women with a serum 25(OH) D concentration, $<20 \mathrm{ng} / \mathrm{mL}$ compared with those with values $>30 \mathrm{ng} / \mathrm{mL}$ [52]. In another study, the prevalence of bacterial vaginosis increased 1.65-fold and 1.26-fold at serum concentrations of $8 \mathrm{ng} / \mathrm{mL}$ and $20 \mathrm{ng} / \mathrm{mL}$, respectively compared to $>30 \mathrm{ng} / \mathrm{mL}$ [53]. Also maternal serum 25(OH) D $<30 \mathrm{ng} / \mathrm{mL}$ during early pregnancy has been associated with a two-fold increased risk of periodontal disease [54]. Vitamin D status in infant cord blood has been related to the innate immune response via toll-like receptor-mediated synthesis of antimicrobial peptides like cathelicidin [55]. The risk of respiratory syncytial virus bronchiolitis in the first year of life is increased by six-fold in infants with cord blood 25(OH) D $<20 \mathrm{ng} / \mathrm{mL}$ compared with infants with 25(OH) D $>30$ $\mathrm{ng} / \mathrm{mL}$. Cord blood 25(OH) D concentrations $<30 \mathrm{ng} / \mathrm{mL}$ have also been linked to infantile wheezing [56] and eczema [57].

The Institute of Medicine (IOM) currently recommends a normal level of $20 \mathrm{ng} / \mathrm{mL}$ in pregnancy [58]. There is a growing consensus that the serum Vitamin D levels below $20 \mathrm{ng} / \mathrm{mL}$ represents deficiency is a practice based on skeletal actions of Vitamin D which is debated and higher target is required for extra-skeletal benefits. The Endocrine Society and the Vitamin D experts recommend a higher target of $>30 \mathrm{ng} / \mathrm{mL}$ in order to achieve optimal benefits for skeletal as well as extra-skeletal benefits [32]. Literature also suggest a level $>40 \mathrm{ng} / \mathrm{mL}$ in pregnancy is safe to support $1,25(\mathrm{OH})_{2}$ D production by overcoming substrate limitation as well [59]. Given the mounting evidence of benefits of Vitamin D supplementation in pregnancy and lactation, we feel that there is substantial progress in research in this area which supports raising the optimal serum Vitamin $\mathrm{D}$ levels to be $>30$ $\mathrm{ng} / \mathrm{mL}$ in pregnancy and lactation. As previously stated, with widespread deficiency statistics across the country; there is an urgent need to at least maintain all pregnant and lactating mothers under the sufficiency belt. Given the substantial scope of better outcomes with higher levels, there is need of further research to study the outcomes at these higher Vitamin D levels.

\section{Vitamin D Recommendations}

The Recommended Daily Allowances of Vitamin D in pregnancy and lactation has underwent a fast surging change as the data of deficiencies surface, compelling International committees to upgrade their recommendations. The Institute of Medicines (IOM) in 1997 recommended Vitamin D intake of 200 IU citing there is no additional need to increase the Vitamin D intake during pregnancy above that required for non-pregnant women. Even the recommendation during lactation were 200 IU citing that there is no evidence to indicate that lactation increases a mother's actual intake of Vitamin D [60]. The Institute of Medicines (IOM) currently recommends 
daily intake of 600 IU Vitamin D in pregnancy and lactation. This recommendation is provided for achieving the recommended target serum 25(OH) D concentration of $20 \mathrm{ng} / \mathrm{mL}$ by IOM. Table 3 describes the former and current recommended Vitamin D intakes in pregnancy and lactation by various institutions including Indian Council of Medical Research (ICMR).

There is an increasing debate among the world bodies on recommended daily allowances (RDAs) of Vitamin D. Many researchers suggest that RDA of 600 IU or less Vitamin D may not be sufficient in correcting Vitamin D deficiency. Recently, the American Congress of Obstetrics and Gynecology (ACOG) committee opined that for pregnant women thought to be at increased risk of Vitamin D deficiency, maternal serum 25-hydroxyvitamin $\mathrm{D}$ levels can be considered and should be interpreted in the context of the individual clinical circumstance [61]. Results of the recently conducted randomized controlled trial on Vitamin D supplementation in pregnancy suggest a safe dose of 2000 - 4000 IU/day [50] [51] [59] [62] [63] sufficient to maintain the levels above $30 \mathrm{ng} / \mathrm{mL}$. The US Endocrine Society Guidelines, 2011 recognizes that pregnant women would require at least 1500 - 2000 $\mathrm{IU} / \mathrm{d}$ of Vitamin D to maintain a blood level of 25(OH)D above $30 \mathrm{ng} / \mathrm{ml}$ (sufficient level) \& lactating women may need at a minimum $1400-1500 \mathrm{IU} / \mathrm{d}$. To satisfy the requirements of an infant who is fed only breast milk, the mother requires 4000 to 6000 IU/d to transfer enough Vitamin D into her milk [32]. The Canadian Pediatric Society mentions consideration should be given to administering 2000 IU of Vitamin D daily to pregnant \& lactating women, especially during the winter months, to maintain Vitamin D sufficiency [64]. The American Congress of Obstetricians \& Gynecologists (ACOG), 2011 Committee recognizes that use of 1000 - 2000 IU/day of Vitamin D is safe when Vitamin D deficiency is identified during pregnancy [61]. Table 4 summarizes the Vitamin D recommendations by world committees in Pregnancy and Lactation.

Currently in India, no national guidelines recommend routine Vitamin D supplementation in pregnancy and lactation. With the growing evidence that adequate maternal Vitamin D status is essential during pregnancy, not only for maternal well-being but also for fetal development [66]-[69], clinicians should consider assessing maternal Vitamin D status during pregnancy and lactation. On an individual basis, a mother should be supplemented with adequate amounts of Vitamin D to ensure that her 25(OH) D levels are in a sufficient range ( $>32$ $\mathrm{ng} / \mathrm{mL}$ ) [70]-[73]. Sufficient numbers of women of reproductive age are assumed to obtain their recommended intake of vitamins through prenatal vitamin supplementation. This is probably due to less clarity with respect to dosage, timing and route of administration during pregnancy and lactation. The knowledge that prenatal vitamins containing $400 \mathrm{IU}$ of Vitamin D have little effect on circulating maternal 25(OH) D concentrations, especially during the winter months, should be imparted to all clinicians involved in the care of pregnant women and lactating mothers in India.

Table 3. Shifting opinions of Vitamin D intake in pregnancy and lactation.

\begin{tabular}{|cccccc}
\hline \multicolumn{2}{c}{ Institute of Medicines (IOM) } & Endocrine Society & $\begin{array}{c}\text { Indian Council of Medical } \\
\text { Research (ICMR) }\end{array}$ \\
\hline RDA (1997) & RDA (2011) & UL (2011) & Daily Requirement (2011) & UL (2011) & Daily Requirement (2010) \\
\hline $200 \mathrm{IU}$ & $600 \mathrm{IU}$ & $4000>19$ yrs. & $1500-2000 \mathrm{IU}$ & $10000>19$ yrs. & $400 \mathrm{IU}$ \\
\hline
\end{tabular}

Abbreviations: IU, International unit; RDA, Recommended Daily Allowance; UL, Upper limit.

Table 4. Vitamin D recommendations by world committees in pregnancy and lactation.

\begin{tabular}{cc}
\hline Committees & Recommendation \\
\hline National Institute for Health and Care Excellence (NICE) guidelines, UK [65] & 400 IU \\
Institute of Medicines (IOM) [58] & $600 \mathrm{IU}$ \\
Endocrine Society [32] & $1500-2000 \mathrm{IU}$ \\
Canadian Pediatric Society [64] & $2000 \mathrm{IU}$ \\
American Congress of Obstetricians \& Gynecologists (ACOG) [61] & $1000-2000 \mathrm{IU}$ \\
\hline
\end{tabular}




\section{Vitamin D Supplementation before and Soon after Pregnancy?}

Preconceptional counseling is different from antenatal care. In particular, it is more important than antenatal care, as $30 \%$ of pregnant women begin traditional antenatal care in the second trimester and after the period of maximal organogenesis (between 3 and 10 weeks' gestation) [74]. Preconception care refers to interventions that aim to identify and modify biomedical, behavioral and social risks to women's health or pregnancy outcome through prevention and management. A number of observational studies provide the link between low Vitamin D levels in first trimester and pregnancy outcome. Studies have shown that low 25(OH) D levels at first trimester are an independent risk factor for developing gestational diabetes mellitus and associated with insulin resistance at second trimester [75]. 50\% of obese women in the first trimester had serum 25(OH) D concentrations < $20 \mathrm{ng} / \mathrm{mL}$ indicating deficiency in first trimester is a concern [76]. Among pregnant women in their first trimester, 57\% women had bacterial vaginosis with Vitamin D levels $<20 \mathrm{ng} / \mathrm{mL}$. First-trimester 25(OH) D levels of less than $15 \mathrm{ng} / \mathrm{mL}$ were related to the development of pre-eclampsia [77]. More elaborate observational studies are required to elucidate a better conclusion with respect to first trimester usage, since few trials also show no association between Vitamin D levels in first trimester and pregnancy outcomes. Interventional studies are emerging showing Vitamin D supplementation is safe and useful in overcoming deficiency in first trimester. These studies could be cornerstone for call on consensus for Vitamin D supplementation in first trimester of pregnancy. In a Qatar Study, pregnant women supplemented weekly oral dose of 50,000 IU from first trimester resulted in improvement of maternal Vitamin D levels. Newborns' Vitamin D levels could correlate with the Vitamin D level of their mothers [78]. In another Middle-east study, supplementation of oral 2000 IU/day in preconception period showed positive effect on Vitamin D levels in reproductive women [79]. Such studies should further be carried out to demonstrate the effect of safe dose of Vitamin D in the short time of preconception period which is about 2 or 3 month before being pregnant, to avoid concurrency of Vitamin D deficiency in the early stages of embryonic life and pregnancy.

\section{Vitamin D Treatment Strategy in Pregnancy and Lactation}

A review of randomized controlled trials of Vitamin D supplementation during pregnancy indicates that doses of 400 - 1600 IU/day were insufficient in achieving even a mean serum 25(OH) D concentration $\geq 20 \mathrm{ng} / \mathrm{mL}$ [66]. However, getting 25(OH) D levels consistently above $30 \mathrm{ng} / \mathrm{mL}$ may require at least 1500 - $2000 \mathrm{IU} / \mathrm{day}$ of Vitamin D [32]. Studies have shown that Vitamin D intake of up to 10,000 IU/day for 5 months is associated with achievement of a serum $25(\mathrm{OH}) \mathrm{D}$ concentration $\geq 32 \mathrm{ng} / \mathrm{mL}$ without Vitamin D toxicity [80] [81]. A number of trials have suggested that doses of $2000 \mathrm{IU}-4000 \mathrm{IU}$ would be required to maintain serum $25(\mathrm{OH}) \mathrm{D} \geq 32 \mathrm{ng} / \mathrm{mL}$. In a recent trial studying the effect of two dose regimens, pregnant women with low 25(OH) D levels were randomized to 2000 IU vitamin D3/d or 400 IU/d from $<20$ week gestation until delivery. 25(OH)D was significantly greater in the treatment group at both 26 (41 vs. $34 \mathrm{ng} / \mathrm{mL}$ ) and 36 week (46 vs. $34 \mathrm{ng} / \mathrm{mL})$ suggesting that a daily dose of $2000 \mathrm{IU}$ is effective at improving Vitamin D status in pregnant women [82]. Bruce W Hollis et al. [50] described a randomized, controlled trial, including 350 women with a singleton pregnancy at 12 to 16 weeks' gestation supplemented with 400 IU, 2000 IU, or 4000 IU of Vitamin D per day until delivery. Not a single adverse event was attributed to Vitamin D supplementation or circulating 25(OH) D levels. 82\%, 71\%, and 50\%, respectively, of the mothers on $4000 \mathrm{IU}, 2000 \mathrm{IU}$, and $400 \mathrm{IU}$ of Vitamin D daily achieved a serum 25(OH) D concentration > $32 \mathrm{ng} / \mathrm{mL}$. The authors concluded that Vitamin D supplementation of 4000 IU/day for pregnant women is safe and most effective in achieving sufficiency in all women and their neonates regardless of race. Carol L. Wagner et al. [51] studied safety of 2000 IU and 4000 IU Vitamin D in pregnancy \& determine if maternal/fetal 25(OH) D improves in dose-dependent manner. In the study of 257 pregnant women supplemented from 12 - 16 weeks' gestation, the authors concluded that maternal supplementation with Vitamin D 2000 IU/d and 4000 IU/d during pregnancy improved maternal/neonatal Vitamin D status. Evidence of risk reduction in infection, preterm labor, and preterm birth was suggestive, requiring additional studies powered for these endpoints. The new RCT data indicate that 4000 IU/day Vitamin D during pregnancy will "normalize" Vitamin D metabolism and improve birth outcomes including primary cesarean section and comorbidities of pregnancy with no risk of side effects [74]. In a United Arab Emirates (UAE) study, oral Vitamin $\mathrm{D}_{2}$ supplementation with $2000 \mathrm{IU} / \mathrm{d}$ or 60,000 IU/month for 3 month was safe, and it increased serum 25(OH) D concentrations significantly during lactation [83]. In another study, it was found that a maternal intake of 2000 IU/d Vitamin D would elevate circulating 25(OH) D concentrations for both mothers and nursing infants, albeit with 
limited capacity, especially with respect to nursing infants. A maternal intake of $4000 \mathrm{IU} / \mathrm{d}$ could achieve substantial progress toward improving both maternal and neonatal nutritional Vitamin D status [84]. In a study from the United Arab Emirates, among pregnant Arab women with a high prevalence of Vitamin D deficiency suggested that Vitamin D supplementation of 2000 and $4000 \mathrm{IU} / \mathrm{d}$ appeared safe in pregnancy, and $4000 \mathrm{IU} / \mathrm{d}$ was most effective in optimizing serum 25(OH) D concentrations in mothers and their infants as compared to 400 IU/d [62].

\section{Clinical Evidence-Indian Outlook}

Although interventional trials in Indian population are scarce, as the Vitamin D deficiency awareness increases, an increasing population is being subjected to Vitamin D supplementation. Marya et al. [85] suggested that Vitamin D (1200 IU/day) during 32 and 36 weeks of pregnancy was associated with significant reduction systolic blood pressure (SBP) and diastolic blood pressure (DBP) than non-supplemented group. The same author had previously demonstrated that $1200 \mathrm{U}$ Vitamin D/day throughout the $3^{\text {rd }}$ trimester, showed significantly lower Heat-liable alkaline phosphatase (HLAP) levels and increased fetal birth weight [86].

Higher doses (i.e. 50,000 IU, 60,000 IU) are yet to be adapted as safe or either talked about in pregnancy. It is noteworthy that these doses are already studied among Indian population and appear to be safe in once a month dosing during second and third trimester. Marya RL et al. [86] suggested that administration of Vitamin D in two large doses of 60,000 IU each in the 7th and 8th months of pregnancy in 20 women was more efficacious. Jasbinder Kaur et al. [87] described the effect of administration of two pharmacological doses of Vitamin D (60,000 IU each) in 6th and 7th months of pregnancy. Compared to controls, the birth weight and weight of the placenta, its protein, DNA and RNA contents were significantly higher in the supplemented group. Kalra P. et al. [26] studied the effect of Vitamin D supplementation in two groups. Of pregnant women, one group received single oral 60,000 IU dose (second trimester) and other group received two oral doses of 120,000 IU (second and third trimester respectively) in pregnancy. Both doses improved infant anthropometry whereas the larger dose also increased maternal Vitamin D levels. Sahu et al. [88] reported that among 60,000 IU in fifth month and 120,000 IU in fifth and seventh month, Vitamin D in doses 120,000 IU in 5th and 7th was effective in raising the 25(OH) D levels in pregnancy. Parul Singla et al. [89] studied 100 pregnant women who received 60,000 IU every fortnight from 28 till 36 week of gestation. Vitamin D supplementation during the third trimester of pregnancy was found to be efficacious in reducing the risk of preeclampsia by increasing therapeutic effectiveness of calcium supplementation in pregnant women. It could be possible that higher number of Indian trials with 60,000 IU/ month usually among fifth and seventh trimester indicated better patient compliance as compared to $2000 \mathrm{IU} / 4000 \mathrm{IU}$ per day doses.

With doses about 2000 IU - 4000 IU found to be safe and recommended by various committees, further randomized controlled trials among Indian population could be beneficial in defining the safe dose and duration of Vitamin D supplementation in pregnancy and lactation. There is substantial evidence that a higher dose (60,000 IU) per month does not show any clinical side effects in Vitamin D deficient pregnant women. A consensus of recommendation on higher doses is required by global committees, a fact to be discussed for inclusion in international guidelines. Further data in this perspective would be welcoming.

\section{Conclusion}

As calcium demands increase in pregnancy, Vitamin D status becomes crucial for optimal maternal \& fetal outcomes. Low levels of Vitamin D are linked with a number of fetal health problems like small size, neonatal hypocalcaemia \& seizures, impaired growth, skeletal problems including rickets \& low BMD. Low levels of Vitamin $\mathrm{D}$ are linked with a number of maternal health problems like preeclampsia, preterm labour $\&$ an increased rate of caesarean section. The high incidences of Vitamin D deficiency in pregnancy and lactation in India call for unanimous approach to tackle this grave situation. It is also a concern that despite such high deficiency statistics, there is no national consensus statement for clarity on prevention and treatment of this deficiency. Following the evidence, there is substantial need for upgradation of target Vitamin D level to be maintained above $30 \mathrm{ng} / \mathrm{mL}$ in pregnancy and lactation. There is a need to further elaborate the effect of Vitamin D supplementation through randomized controlled trials with appropriate doses (2000 IU, $4000 \mathrm{IU}, 60,000 \mathrm{IU}$ ) to further gain clarity for its beneficial clinical practice across all trimesters \& beyond. 


\section{References}

[1] Van Schoor, N.M. and Lips, P. (2011) Worldwide Vitamin D Status. Best Practice \& Research Clinical Endocrinology \& Metabolism, 25, 671-680. http://dx.doi.org/10.1016/j.beem.2011.06.007

[2] Mithal, A., Wahl, D.A., Bonjour, J.P., Burckhardt, P., Dawson-Hughes, B., Eisman, J.A., El-Hajj Fuleihan, G., Josse, R.G., Lips, P. and Morales-Torres, J., IOF Committee of Scientific Advisors (CSA) Nutrition Working Group (2009) Global Vitamin D Status and Determinants of Hypovitaminosis D. Osteoporosis International, 20, 1807-1820. http://dx.doi.org/10.1007/s00198-009-0954-6

[3] Van der Meer, I.M., Middelkoop, B.J., Boeke, A.J. and Lips, P. (2011) Prevalence of Vitamin D Deficiency among Turkish, Moroccan, Indian and Sub-Sahara African Populations in Europe and Their Countries of Origin: An Overview. Osteoporosis International, 22, 1009-1021. http://dx.doi.org/10.1007/s00198-010-1279-1

[4] Rathi, N. and Rathi, A. (2011) Vitamin D and Child Health in 21st Century. Indian Pediatrics, 48, 619-625. http://dx.doi.org/10.1007/s13312-011-0107-9

[5] Londhey, V. (2011) Vitamin D Deficiency: Indian Scenario. Journal of the Association of Physicians of India, 59, 695696.

[6] Seshadria, KG., Tamilselvana, B. and Rajendrana, A. (2011) Role of Vitamin D in Diabetes. Journal of Clinical Endocrinology \& Metabolism, 1, 47-56.

[7] Wang, T.J., Pencina, M.J., Booth, S.L., Jacques, P.F., Ingelsson, E., Lanier, K., Benjamin, E.J., D’Agostino, R.B., Wolf, M. and Vasan, R.S. (2008) Vitamin D Deficiency and Risk of Cardiovascular Disease. Circulation, 117, 503511. http://dx.doi.org/10.1161/CIRCULATIONAHA.107.706127

[8] Holick, M.F. (2010) Vitamin D Physiology, Molecular Biology, and Clinical Applications. Nutrition and Health, Humana Press, XXVI, 1160.

[9] Mulligan, M.L., Felton, S.K., Riek, A.E. and Bernal-Mizrachi, C. (2010) Implications of Vitamin D Deficiency in Pregnancy and Lactation. American Journal of Obstetrics \& Gynecology, 202, 429, e1-e9.

[10] Wagner, C.L., Taylor, S.N., Dawodu, A., Johnson, D.D. and Hollis, B.W. (2012) Vitamin D and Its Role during Pregnancy in Attaining Optimal Health of Mother and Fetus. Nutrients, 4, 208-230. http://dx.doi.org/10.3390/nu4030208

[11] Lucas, R.M., Ponsonby, A.L., Pasco, J.A. and Morley, R. (2008) Future Health Implications of Prenatal and Early-Life Vitamin D Status. Nutrition Reviews, 66, 710-720. http://dx.doi.org/10.1111/j.1753-4887.2008.00126.x

[12] Thorne-Lyman, A. and Fawzi, W.W. (2012) Vitamin D during Pregnancy and Maternal, Neonatal and Infant Health Outcomes: A Systematic Review and Meta-Analysis. Paediatric and Perinatal Epidemiology, 26, 75-90. http://dx.doi.org/10.1111/j.1365-3016.2012.01283.x

[13] Goswami, R., Gupta, N., Goswami, D., Marwaha, R.K., Tandon, N. and Kochupillai, N. (2000) Prevalence and Significance of Low 25-Hydroxyvitamin D Concentrations in Healthy Subjects in Delhi. American Journal of Clinical Nutrition, 72, 472-475.

[14] Balasubramanian, K., Rajeswari, J., Gulab, Govil, Y.C., Agarwal, A.K., Kumar, A. and Bhatia, V. (2003) Varying Role of Vitamin D Deficiency in the Etiology of Rickets in Young Children vs. Adolescents in Northern India. Journal of Tropical Pediatrics, 49, 201-206. http://dx.doi.org/10.1093/tropej/49.4.201

[15] Clements, M.R., Johnson, L. and Fraser, D.R. (1987) A New Mechanism for Induced Vitamin D Deficiency in Calcium Deprivation. Nature, 325, 62-65. http://dx.doi.org/10.1038/325062a0

[16] Agarwal, K.S., Mughal, M.Z., Upadhyay, P., Berry, J.L., Mawer, E.B. and Puliyel, J.M. (2002) The Impact of Atmospheric Pollution on Vitamin D Status of Infants and Toddlers in Delhi, India. Archives of Disease in Childhood, 87, 111-113. http://dx.doi.org/10.1136/adc.87.2.111

[17] Sahu, M., Bhatia, V., Aggarwal, A., Rawat, V., Saxena, P., Pandey, A. and Das, V. (2009) Vitamin D Deficiency in Rural Girls and Pregnant Women Despite Abundant Sunshine in Northern India. Clinical Endocrinology, 70, 680-684. http://dx.doi.org/10.1111/j.1365-2265.2008.03360.x

[18] Sachan, A., Gupta, R., Das, V., Agarwal, A., Awasthi, P.K. and Bhatia, V. (2005) High Prevalence of Vitamin D Deficiency among Pregnant Women and Their Newborns in Northern India. American Journal of Clinical Nutrition, 81, 1060-1064.

[19] Bhalala, U., Desai, M., Parekh, P., Mokal, R. and Chheda, B. (2007) Subclinical Hypovitaminosis D among Exclusively Breastfed Young Infants. Indian Pediatrics, 44, 897-901.

[20] Farrant, H.J., Krishnaveni, G.V., Hill, J.C., Boucher, B.J., Fisher, D.J., Noonan, K., Osmond, C., Veena, S.R. and Fall, C.H. (2009) Vitamin D Insufficiency Is Common in Indian Mothers but Is Not Associated with Gestational Diabetes or Variation in Newborn Size. European Journal of Clinical Nutrition, 63, 646-652. http://dx.doi.org/10.1038/ejcn.2008.14

[21] Agarwal, N. and Arya, S.C. (2011) Vitamin D3 Levels in Pregnant Women and Newborns at a Private Tertiary Care 
Hospital in Delhi, India. International Journal of Gynecology \& Obstetrics, 113, 240-241. http://dx.doi.org/10.1016/j.ijgo.2011.01.005

[22] Krishnaveni, G.V., Veena, S.R., Winder, N.R., Hill, J.C., Noonan, K., Boucher, B.J., Karat, S.C. and Fall, C.H. (2011) Maternal Vitamin D Status during Pregnancy and Body Composition and Cardiovascular Risk Markers in Indian Children: The Mysore Parthenon Study. American Journal of Clinical Nutrition, 93, 628-635. http://dx.doi.org/10.3945/ajcn.110.003921

[23] Marwaha, R.K., Tandon, N., Chopra, S., Agarwal, N., Garg, M.K., Sharma, B., Kanwar, R.S., Bhadra, K., Singh, S., Mani, K. and Puri, S. (2011) Vitamin D Status in Pregnant Indian Women across Trimesters and Different Seasons and Its Correlation with Neonatal Serum 25-hydroxyvitamin D Levels. British Journal of Nutrition, 106, 1383-1389. http://dx.doi.org/10.1017/S000711451100170X

[24] Dasgupta, A., Saikia, U. and Sarma, D. (2012) Status of 25(OH)D Levels in Pregnancy: A Study from the North Eastern Part of India. Indian Journal of Endocrinology and Metabolism, 16, S405-S407.

[25] Mave, V., Shere, D., Gupte, N., Suryavanshi, N., Kulkarni, V., Patil, S., Khandekar, M., Kinikar, A., Bharadwaj, R., Bhosale, R., Sambarey, P., Chandanwale, A., Bollinger, R. and Gupta, A., SWEN India and Byramjee-Jeejeebhoy Medical College Clinical Trials Unit Study Team (2012) Vitamin D Deficiency Is Common among HIV-Infected Breastfeeding Mothers in Pune, India, but Is Not Associated with Mother-to-Child HIV Transmission. HIV Clinical Trials, 13, 278-283. http://dx.doi.org/10.1310/hct1305-278

[26] Kalra, P., Das, V., Agarwal, A., Kumar, M., Ramesh, V., Bhatia, E., Gupta, S., Singh, S., Saxena, P. and Bhatia, V. (2012) Effect of Vitamin D Supplementation during Pregnancy on Neonatal Mineral Homeostasis and Anthropometry of the Newborn and Infant. British Journal of Nutrition, 108, 1052-1058. http://dx.doi.org/10.1017/S0007114511006246

[27] Jani, R., Palekar, S., Munipally, T., Ghugre, P. and Udipi, S. (2014) Widespread 25-Hydroxyvitamin D Deficiency in Affluent and Nonaffluent Pregnant Indian Women. BioMed Research International, 2014, Article ID: 892162, 8 pages.

[28] Seth, A., Marwaha, R.K., Singla, B., Aneja, S., Mehrotra, P., Sastry, A., Khurana, M.L., Mani, K., Sharma, B. and Tandon, N. (2009) Vitamin D Nutritional Status of Exclusively Breast Fed Infants and Their Mothers. Journal of Pediatric Endocrinology and Metabolism, 22, 241-246. http://dx.doi.org/10.1515/JPEM.2009.22.3.241

[29] Mehrotra, P., Marwaha, R.K., Aneja, S., Seth, A., Singla, B.M., Ashraf, G., Sharma, B., Sastry, A. and Tandon, N. (2010) Hypovitaminosis D and Hypocalcemic Seizures in Infancy. Indian Pediatrics, 47, 581-586. http://dx.doi.org/10.1007/s13312-010-0131-1

[30] Agarwal, N., Faridi, M.M., Aggarwal, A. and Singh, O. (2010) Vitamin D Status of Term Exclusively Breastfed Infants and Their Mothers from India. Acta Paediatrica, 99, 1671-1674. http://dx.doi.org/10.1111/j.1651-2227.2010.01912.x

[31] Jain, V., Gupta, N., Kalaivani, M., Jain, A., Sinha, A. and Agarwal, R. (2011) Vitamin D Deficiency in Healthy Breastfed Term Infants at 3 Months \& Their Mothers in India, Seasonal Variation \& Determinants. Indian Journal of Medical Research, 133, 267-273.

[32] Holick, M.F., Binkley, N.C., Bischoff-Ferrari, H.A., Gordon, C.M., Hanley, D.A., Heaney, R.P., Murad, M.H. and Weaver, C.M., Endocrine Society (2011) Evaluation, Treatment, and Prevention of Vitamin D Deficiency: An Endocrine Society Clinical Practice Guideline. Journal of Clinical Endocrinology \& Metabolism, 96, 1911-1930. http://dx.doi.org/10.1210/jc.2011-0385

[33] Barrett, H. and McElduff, A. (2010) Vitamin D and Pregnancy: An Old Problem Revisited. Best Practice \& Research Clinical Endocrinology \& Metabolism, 24, 527-539. http://dx.doi.org/10.1016/j.beem.2010.05.010

[34] Bodnar, L.M., Catov, J.M., Simhan, H.N., Holick, M.F., Powers, R.W. and Roberts, J.M. (2007) Maternal Vitamin D Deficiency Increases the Risk of Preeclampsia. Journal of Clinical Endocrinology \& Metabolism, 92, 3517-3522. http://dx.doi.org/10.1210/jc.2007-0718

[35] Arora, C.P. and Hobel, C.J. (2010) Vitamin D and IL-6 in Pregnancies with Subsequent Preterm Birth. Reproductive Sciences, 17, 179À-180À.

[36] Chander, P.A. and Hobel, C.J. (2010) Vitamin D-A Novel Role in Pregnancy. Biopolymers and Cell, 26, 97-104. http://dx.doi.org/10.7124/bc.00014B

[37] Merewood, A., Mehta, S.D., Chen, T.C., Bauchner, H. and Holick, M.F. (2009) Association between Vitamin D Deficiency and Primary Cesarean Section. Journal of Clinical Endocrinology \& Metabolism, 94, 940-945. http://dx.doi.org/10.1210/jc.2008-1217

[38] Javaid, M.K., Crozier, S.R., Harvey, N.C., Gale, C.R., Dennison, E.M., Boucher, B.J., Arden, N.K., Godfrey, K.M. and Cooper, C., Princess Anne Hospital Study Group (2006) Maternal Vitamin D Status during Pregnancy and Childhood Bone Mass at Age 9 Years: A Longitudinal Study. Lancet, 367, 36-43. http://dx.doi.org/10.1016/S0140-6736(06)67922-1 
[39] Morley, R., Carlin, J.B., Pasco, J.A. and Wark, J.D. (2006) Maternal 25-Hydroxyvitamin D and Parathyroid Hormone Concentrations and Offspring Birth Size. Journal of Clinical Endocrinology \& Metabolism, 91, 906-912. http://dx.doi.org/10.1210/jc.2005-1479

[40] Scholl, T.O. and Chen, X. (2009) Vitamin D Intake during Pregnancy: Association with Maternal Characteristics and Infant Birth Weight. Early Human Development, 85, 231-234. http://dx.doi.org/10.1016/j.earlhumdev.2008.10.006

[41] Leffelaar, E.R., Vrijkotte, T.G. and van Eijsden, M. (2010) Maternal Early Pregnancy Vitamin D Status in Relation to Fetal and Neonatal Growth: Results of the Multi-Ethnic Amsterdam Born Children and Their Development Cohort. British Journal of Nutrition, 104, 108-117. http://dx.doi.org/10.1017/S000711451000022X

[42] Hillman, L.S. and Haddad, J.G. (1974) Human Perinatal Vitamin D Metabolism, I: 25-Hydroxyvitamin D in Maternal and Cord Blood. Journal of Pediatrics, 84, 742-749. http://dx.doi.org/10.1016/S0022-3476(74)80024-7

[43] Ala-Houhala, M. (1985) 25-Hydroxyvitamin D Levels during Breast-Feeding with or without Maternal or Infantile Supplementation of Vitamin D. Journal of Pediatric Gastroenterology \& Nutrition, 4, 220-226. http://dx.doi.org/10.1097/00005176-198504000-00011

[44] Hollis, B.W., Roos, B.A., Draper, H.H. and Lambert, P.W. (1981) Vitamin D and Its Metabolites in Human and Bovine Milk. Journal of Nutrition, 111, 1240-1248.

[45] Hatun, S., Ozkan, B., Orbak, Z., Doneray, H., Cizmecioglu, F., Toprak, D. and Calikoglu, A.S. (2005) Vitamin D Deficiency in Early Infancy. Journal of Nutrition, 135, 279-282.

[46] Muhe, L., Lulseged, S., Mason, K.E. and Simoes, E.A. (1997) Case-Control Study of the Role of Nutritional Rickets in the Risk of Developing Pneumonia in Ethiopian Children. Lancet, 349, 1801-1804. http://dx.doi.org/10.1016/S0140-6736(96)12098-5

[47] Zittermann, A., Schleithoff, S.S. and Koerfer, R. (2005) Putting Cardiovascular Disease and Vitamin D Insufficiency into Perspective. British Journal of Nutrition, 94, 483-492. http://dx.doi.org/10.1079/BJN20051544

[48] Hollis, B.W. (2005) Circulating 25-Hydroxyvitamin D Levels Indicative of Vitamin D Sufficiency, Implications for Establishing a New Effective Dietary Intake Recommendation for Vitamin D. Journal of Nutrition, 135, 317-322.

[49] Hollis, B.W. and Wagner, C.L. (2006) Vitamin D Deficiency during Pregnancy: An Ongoing Epidemic. American Journal of Clinical Nutrition, 84, 273.

[50] Hollis, B.W., Johnson, D., Hulsey, T.C., Ebeling, M. and Wagner, C.L. (2011) Vitamin D Supplementation during Pregnancy, Double-Blind, Randomized Clinical Trial of Safety and Effectiveness. Journal of Bone and Mineral Research, 26, 2341-2357. http://dx.doi.org/10.1002/jbmr.463

[51] Wagner, C.L., McNeil, R., Hamilton, S.A., Winkler, J., Rodriguez Cook, C., Warner, G., Bivens, B., Davis, D.J., Smith, P.G., Murphy, M., Shary, J.R. and Hollis, B.W. (2013) A Randomized Trial of Vitamin D Supplementation in 2 Community Health Center Networks in South Carolina. American Journal of Obstetrics and Gynecology, 208, 137.e1137.e13.

[52] Baker, A.M., Haeri, S., Camargo Jr., C.A., Espinola, J.A. and Stuebe, A.M. (2010) A Nested Case-Control Study of Midgestation Vitamin D Deficiency and Risk of Severe Preeclampsia. Journal of Clinical Endocrinology \& Metabolism, 95, 5105-5109. http://dx.doi.org/10.1210/jc.2010-0996

[53] Bodnar, L.M., Krohn, M.A. and Simhan, H.N. (2009) Maternal Vitamin D Deficiency Is Associated with Bacterial Vaginosis in the First Trimester of Pregnancy. Journal of Nutrition, 139, 1157-1161. http://dx.doi.org/10.3945/jn.108.103168

[54] Boggess, K.A., Espinola, J.A., Moss, K., Beck, J., Offenbacher, S. and Camargo Jr., C.A. (2011) Vitamin D Status and Periodontal Disease among Pregnant Women. Journal of Periodontology, 82, 195-200. http://dx.doi.org/10.1902/jop.2010.100384

[55] Walker, V.P., Zhang, X., Rastegar, I., Liu, P.T., Hollis, B.W., Adams, J.S. and Modlin, R.L. (2011) Cord Blood Vitamin D Status Impacts Innate Immune Responses. Journal of Clinical Endocrinology \& Metabolism, 96, 1835-1843. http://dx.doi.org/10.1210/jc.2010-1559

[56] Camargo Jr., C.A., Ingham, T., Wickens, K., Thadhani, R., Silvers, K.M., Epton, M.J., Town, G.I., Pattermore, P.K. and Espinola, J.A., New Zealand Asthma and Allergy Cohort Study Group (2011) Cord-Blood 25-Hydroxyvitamin D Levels and Risk of Respiratory Infection, Wheezing, and Asthma. Pediatrics, 127, e180-e187. http://dx.doi.org/10.1542/peds.2010-0442

[57] Jones, A.P., Palmer, D., Zhang, G. and Prescott, S.L. (2012) Cord Blood 25-Hydroxyvitamin D3 and Allergic Disease during Infancy. Pediatrics, 130, e1128-e1135. http://dx.doi.org/10.1542/peds.2012-1172

[58] Food and Nutrition Board, Standing Committee in the Scientific Evaluation of Dietary References Intakes (2010) Dietary Reference Intakes for Vitamin D and Calcium. National Academics Press, Washington DC, 291-340.

[59] Hollis, B.W. and Wagner, C.L. (2013) Vitamin D and Pregnancy: Skeletal Effects, Nonskeletal Effects, and Birth 
Outcomes. Calcified Tissue International, 92, 128-139. http://dx.doi.org/10.1007/s00223-012-9607-4

[60] Institute of Medicine (US) Standing Committee on the Scientific Evaluation of Dietary Reference Intakes (1997) Dietary References Intakes for Calcium, Phosphorus, Magnesium, Vitamin D and Fluoride. Standing Committee on the Scientific Evaluation of Dietary Reference Intakes, Food and Nutrition Board, Institute of Medicine. National Academy Press, Washington DC, 250-287.

[61] ACOG Committee on Obstetric Practice (2011) ACOG. Committee Opinion No. 495: Vitamin D: Screening and Supplementation during Pregnancy. Obstetrics \& Gynecology, 118, 197-198. http://dx.doi.org/10.1097/AOG.0b013e318227f06b

[62] Dawodu, A., Saadi, H.F., Bekdache, G., Javed, Y., Altaye, M. and Hollis, B.W. (2013) Randomized Controlled Trial (RCT) of Vitamin D Supplementation in Pregnancy in a Population with Endemic Vitamin D Deficiency. Journal of Clinical Endocrinology \& Metabolism, 98, 2337-2346. http://dx.doi.org/10.1210/jc.2013-1154

[63] Grant, C.C., Stewart, A.W., Scragg, R., Milne, T., Rowden, J., Ekeroma, A., Wall, C., Mitchell, E., Crengle, S., Trenholme, A., Crane, J. and Camargo, C. (2014) Vitamin D during Pregnancy and Infancy and Infant Serum 25-Hydroxyvitamin D Concentration. Pediatrics, 133, e143-e153. http://dx.doi.org/10.1542/peds.2013-2602

[64] Godel, J.C. (2007) Vitamin D Supplementation: Recommendations for Canadian Mothers and Infants. Paediatrics and Child Health, 12, 583-589.

[65] National Institute of Health and Care Excellence Guidelines (2008) Maternal and Child Nutrition. NICE Public Health Guidance 11, London, 1-105. https://www.nice.org.uk/guidance/ph11

[66] Hollis, B.W. and Wagner, C.L. (2004) Assessment of Dietary Vitamin D Requirements during Pregnancy and Lactation. American Journal of Clinical Nutrition, 79, 717-726.

[67] Mannion, C., Gray-Donald, K. and Koski, K. (2006) Association of Low Intake of Milk and Vitamin D during Pregnancy with Decreased Birth Weight. Canadian Medical Association Journal, 174, 1273-1277. http://dx.doi.org/10.1503/cmaj.1041388

[68] Hypponen, E. (2005) Vitamin D for the Prevention of Preeclampsia? A Hypothesis. Nutrition Reviews, 63, $225-232$. http://dx.doi.org/10.1111/j.1753-4887.2005.tb00378.x

[69] Moncrieff, M. and Fadahunsi, T.O. (1974) Congenital Rickets Due to Maternal Vitamin D Deficiency. Archives of Disease in Childhood, 49, 810-811. http://dx.doi.org/10.1136/adc.49.10.810

[70] Hathcock, J.N., Shao, A., Vieth, R. and Heaney, R.P. (2007) Risk Assessment for Vitamin D. American Journal of Clinical Nutrition, 85, 6-18.

[71] Holick, M.F. (2007) Vitamin D Deficiency. New England Journal of Medicine, 357, 266-281. http://dx.doi.org/10.1056/NEJMra070553

[72] Vieth, R., Bischoff-Ferrari, H., Boucher, B.J., Dawson-Hughes, B., Garland, C.F., Heaney, R.P., Holick, B.W., Lamberg-Allardt, C., McGrath, J.J., Norman, A.W., Scragg, R., Whiting, S.J., Willett, W.C. and Zittermann, A. (2007) The Urgent Need to Recommend an Intake of Vitamin D that Is Effective. American Journal of Clinical Nutrition, 86, 649-650.

[73] Hollis, B.W., Wagner, C.L., Kratz, A., Sluss, P.M. and Lewandrowski, K.B. (2005) Normal Serum Vitamin D Levels. New England Journal of Medicine, 352, 515-516. http://dx.doi.org/10.1056/NEJM200502033520521

[74] Hamilton, B.E., Minino, A.M., Martin, J.A., Kochanek, K.D., Strobino, D.M. and Guyer, B. (2007) Annual Summary of Vital Statistics. Pediatrics, 119, 345-360. http://dx.doi.org/10.1542/peds.2006-3226

[75] Lacroix, M., Battista, M.C., Doyon, M., Houde, G., Ménard, J., Ardilouze, J.L., Hivert, M.F. and Perron, P. (2014) Lower Vitamin D Levels at First Trimester Are Associated with Higher Risk of Developing Gestational Diabetes Mellitus. Acta Diabetologica, 51, 609-616. http://dx.doi.org/10.1007/s00592-014-0564-4

[76] Karlsson, T., Andersson, L., Hussain, A., Bosaeus, M., Jansson, N., Osmancevic, A., Hulthén, L., Holmäng, A. and Larsson, I. (2014) Lower Vitamin D Status in Obese Compared with Normal-Weight Women Despite Higher Vitamin D Intake in Early Pregnancy. Clinical Nutrition, xxx, 1-7. http://dx.doi.org/10.1016/j.clnu.2014.09.012

[77] Powe, C.E., Seely, E.W., Rana, S., Bhan, I., Ecker, J., Karumanchi, S.A. and Thadhani, R. (2010) First Trimester Vitamin D, Vitamin D Binding Protein, and Subsequent Preeclampsia. Hypertension, 56, 758-763. http://dx.doi.org/10.1161/HYPERTENSIONAHA.110.158238

[78] Al Emadi, S. and Hammoudeh, M. (2013) Vitamin D Study in Pregnant Women \& Their Babies. Qatar Medical Journal, 1, 32-37.

[79] Taheri, M., Baheiraei, A., Rahimi Foroushani, A. and Modarres, M. (2014) Resolving Vitamin D Deficiency in the Preconception Period among High-Risk Reproductive Women: A Randomized Controlled Trial. Iranian Red Crescent Medical Journal, 16, e11175. http://dx.doi.org/10.5812/ircmj.11175

[80] Vieth, R., Chan, P.C. and MacFarlane, G.D. (2001) Efficacy and Safety of Vitamin D3 Intake Exceeding the Lowest 
Observed Adverse Effect Level. American Journal of Clinical Nutrition, 73, 288-294.

[81] Heaney, R.P., Davies, K.M., Chen, T.C., Holick, M.F. and Barger-Lux, M.J. (2003) Human Serum 25-Hydroxycholecalciferol Response to Extended Oral Dosing with Cholecalciferol. American Journal of Clinical Nutrition, 77, 204210.

[82] Zerofsky, M., Jacoby, B. and Stephensen, C. (2014) A Randomized Controlled Trial of Vitamin D Supplementation in Pregnancy, Effects on Vitamin D Status and Clinical Outcomes. The Journal of the Federation of American Societies of Experimental Biology, 28, Supplement 1041.5.

[83] Saadi, H.F., Dawodu, A., Afandi, B.O., Zayed, R., Benedict, S. and Nagelkerke, N. (2007) Efficacy of Daily and Monthly High-Dose Calciferol in Vitamin D-Deficient Nulliparous and Lactating Women. American Journal of Clinical Nutrition, 85, 1565-1571.

[84] Hollis, B.W. and Wagner, C.L. (2004) Vitamin D Requirements during Lactation: High-Dose Maternal Supplementation as Therapy to Prevent Hypovitaminosis D for both the Mother and the Nursing Infant. American Journal of Clinical Nutrition, 80, 1752S-1758S.

[85] Marya, R.K., Rathee, S. and Manrow, M. (1987) Effect of Calcium and Vitamin D Supplementation on Toxaemia of Pregnancy. Gynecologic and Obstetric Investigation, 24, 38-42. http://dx.doi.org/10.1159/000298772

[86] Marya, R.K., Rathee, S., Lata, V. and Mudgil, S. (1981) Effects of Vitamin D Supplementation in Pregnancy. Gynecologic and Obstetric Investigation, 12, 155-161. http://dx.doi.org/10.1159/000299597

[87] Kaur, J., Marya, R.K., Rathee, S., Lal, H. and Singh, G.P. (1991) Effect of Pharmacological Doses of Vitamin D during Pregnancy on Placental Protein Status and Birth Weight. Nutrition Research, 11, 1077-1081. http://dx.doi.org/10.1016/S0271-5317(05)80400-2

[88] Sahu, M., Das, V., Aggarwal, A., Rawat, V., Saxena, P. and Bhatia, V. (2009) Vitamin D Replacement in Pregnant Women in Rural North India: A Pilot Study. European Journal of Clinical Nutrition, 63, 1157-1159. http://dx.doi.org/10.1038/ejcn.2009.27

[89] Singla, P., Parkash, A.A., Lal, H. and Nanda, S. (2012) Benefits of Vitamin D Supplementation in Pregnancy for Prevention of Preeclampsia. International Journal of Pharmacy \& Biological Sciences, 2, 144-150. 